\title{
RelaÇão entre DistânCia Geográfica e Variabilidade Genética de uMa POPUlaÇÃo de Bidens spp. COM REsistênCIA AOS HERBICIDAS INIBIDORES DE ALS ${ }^{1}$
}

\author{
Relation Between Geographic Distance and Genetic Variability Within a Population of \\ Bidens spp. with Resistance to ALS Inhibitors
}

VIDAL, R.A. ${ }^{2}$, HERNANDES, G.C. ${ }^{3}$, WINKLER, L.M. ${ }^{4}$, FEDERIZZI, L.C. ${ }^{2}$ e DA SILVA, P.R. ${ }^{3}$

\begin{abstract}
RESUMO - Espécies de plantas daninhas apresentam elevada variabilidade genética entre plantas dentro de uma população e exibem potencial para adaptar-se ao manejo realizado para o seu controle. Sementes de picão-preto foram coletadas em uma área retangular de 60 hectares, numa propriedade do município de Almirante Tamandaré do Sul-RS, com suspeita de resistência aos inibidores de ALS e cultivada com soja por aproximadamente 20 anos. Os objetivos deste trabalho foram avaliar a variabilidade genética de acessos de Bidens spp. oriundos de uma única propriedade, verificar a dispersão da resistência na gleba amostrada e determinar a relação entre o coeficiente de similaridade genética e a distância geográfica entre os acessos da mesma população. A área foi dividida em 100 pontos de coleta georreferenciados, dentre os quais apenas 40 possuíam plantas de Bidens spp. Essas sementes foram colocadas em potes plásticos com capacidade de $300 \mathrm{ml}$ e, quando as plântulas apresentavam duas folhas, foram submetidas à aspersão de chlorimuron na dose de $200 \mathrm{~g} \mathrm{ha}^{-1}$, para confirmação da resistência. A extração do DNA foi realizada a partir de adaptações de protocolos existentes na literatura. No mínimo 20 plantas de cada ponto amostrado foram utilizadas para a formação de bulk's de DNA. Vinte e seis primers do kit operon foram utilizados. Os acessos de Bidens spp. apresentaram grande variabilidade genética dentro da população. A análise de RAPD não permitiu separar as espécies Bidens pilosa e Bidens subalternans. A resistência aos herbicidas inibidores de ALS está disseminada em toda a área amostrada dentro da propriedade. Não ocorre relação entre distância geográfica e similaridade genética entre os acessos da população.
\end{abstract}

Palavras-chave: genética, efeito fundador, Bidens pilosa, Bidens subalternans, resistência.

\begin{abstract}
Weed species present high genetic variability among plants within a population and show potential to adapt to control tactics. Seeds of Bidens spp. (BIDSS) were collected in a 60 ha rectangular area, in a property located in Almirante Tamandaré do Sul, RS, with suspected ALS resistance, and cultivated with soybean during approximately 20 years. The objectives of this work were to evaluate the genetic variability of accesses of Bidens spp. collected in only one property, to verify resistance dispersion and to determine the relation between the coefficient of genetic similarity and the geographic distance among accesses of the same population. The area was divided into 100 geo-referenced points of seed samplings, among which only 40 points had BIDSS plants. These seeds had been placed in plastic pots with capacity of $300 \mathrm{~mL}$ and when seedlings presented two leaves, they were sprayed with chlorimuron at a dose of $200 \mathrm{ofg} \mathrm{ha}^{-1}$ for resistance confirmation. DNA extraction was conducted according to the literature protocols. Twenty plants from each sampled site were used for the formation of DNA bulk. Twenty and six primers of the operon kit were also used. The BIDSS accesses presented great genetic variability within the population. RAPD analysis did not allow the separation of the species Bidens pilosa and Bidens subalternans. The resistance to the ALS inhibitors was spread in all the sampled area inside the property. No relation was verified between geographic distance and genetic similarity, suggesting no founder effect occurred in the area.
\end{abstract}

Keywords: $\quad$ genetics, founder effect, Bidens pilosa, Bidens subalternans, resistance.

1 Recebido para publicação em 9.6.2005 e na forma revisada em 24.2.2006.

2 Prof. da Universidade Federal do Rio Grande do Sul -UFRGS, Caixa Postal 15.100, 91501-970 Porto Alegre-RS, pesquisador do CNPq, <ribas.vidal@ufrgs.br>; ${ }^{3}$ M.S. pela UFRGS; ${ }^{4}$ Bolsista Recém-Doutor do CNPq na UFRGS. 


\section{INTRODUÇÃO}

As espécies de plantas daninhas, em geral, apresentam elevada variabilidade genética entre plantas dentro da população ou entre plantas de populações distintas, exibindo assim potencial para adaptar-se ao manejo realizado para o seu controle (Holt \& Hochberg, 1997). A variabilidade genética é um importante prérequisito para a evolução, para o sucesso no estabelecimento e para a dispersão de sementes, sendo encontrada em plantas daninhas (Silverstown \& Lovett Doust, 1993).

A evolução de plantas daninhas deve-se à introdução de novas características advindas de plantas silvestres ou de outras plantas daninhas. Com o desenvolvimento da biologia molecular, é possivel estimar a variabilidade genética dentro da espécie através do uso de marcadores moleculares. Entre as técnicas mais utilizadas para caracterização genética de espécies em que se desconhecem maiores informações genéticas encontram-se os marcadores do tipo RAPD.

Trabalhos com Kochia scoparia obtidos de diferentes locais concluíram que podem ocorrer diferentes mutações no seu genoma. A enzima ALS oriunda de populações distintas apresenta mutações em vários aminoácidos, indicando que existe grande variabilidade dentro da mesma espécie (Guttierri et al., 1992).

Trabalhos realizados com biótipos de Poa annua resistentes e sensiveis aos inibidores do fluxo de elétrons no fotossistema II, para avaliar os polimorfismos morfológico e isoenzimático, demonstraram existir variação genética entre estes. Este estudo não excluiu a possibilidade da ação do efeito fundador produzindo o polimorfismo desses biótipos (Darmency \& Gasquez, 1981). O efeito fundador é definido como o estabelecimento de uma nova população por meio de alguns poucos indivíduos que carregam consigo somente uma pequena fração da variação genética total da população parental (Ridley, 2003). O efeito fundador ocorre quando uma população passa por um efeito denominado gargalo, no qual somente alguns indivíduos da população sobrevivem às alterações no ambiente; a partir destes, a população se expande novamente, podendo colonizar novos ambientes (Ridley, 2003).
Há dúvidas quanto à origem da resistência na propriedade: ela pode ser introduzida no local através da migração de indivíduos (fluxo de genes), ou através de seleção de um biótipo e, a partir deste, aumento da população, ou através de vários efeitos mutacionais dentro da mesma população (Maxwell \& Mortimer, 1994).

Trabalhos que avaliaram a similaridade genética entre biótipos de Euphorbia heterophylla demonstraram que a resistência aos herbicidas inibidores de ALS ocorreu de forma independente nos locais avaliados (Winkler et al., 2002). Contudo, o método de amostragem utilizado nestes trabalhos não foi totalmente adequado, devido à grande extensão territorial amostrada e à falta de georreferenciamento.

Avaliando a dispersão e variação genética de Solanum nigrum resistente e sensivel aos herbicidas inibidores de FS II em 25 locais na França, Polônia e Reino Unido, foi verificada elevada similaridade genética entre as várias populações. O resultado dessa pesquisa sugeriu que a dispersão de sementes de Solanum nigrum ocorreu por meio de aves migratórias entre os países amostrados. Todavia, entre três populações, devido à baixa similaridade encontrada, especula-se que a resistência tenha ocorrido de forma independente (Stankiewicz et al., 2001).

Trabalho realizado para verificar a dispersão de Avena fatua na província de Manitoba (Canadá), com georreferenciamento dos locais de coleta e posterior determinação da resistência para os herbicidas inibidores de ACCase, concluiu que a resistência neste município era localizada em apenas poucos pontos amostrados, mas que a dispersão da resistência para todo o município, através da disseminação de sementes, representava um elevado risco (Bourgeois \& Morrison, 1997). Da teoria especula-se que a análise da relação entre a distância geográfica dos indivíduos amostrados e os respectivos coeficientes de similaridade genética possibilitaria quatro tipos de resultado e respectivas hipóteses explicativas. Em primeiro lugar, a existência de regressão negativa entre ambas as variáveis indicaria que os indivíduos mais próximos apresentariam maior similaridade, e esta decresceria com o aumento da distância, por 
estarem isolados geograficamente/geneticamente. Em segundo lugar, há a possibilidade de ocorrer regressão positiva entre ambas as variáveis, indicando que, à medida que os indivíduos ficam mais distantes entre si, aumenta a similaridade genética entre eles. Esse resultado é pouco provável de ocorrer em plantas daninhas. Em terceiro lugar, quando ocorresse elevada similaridade genética entre os indivíduos amostrados, independentemente da localização geográfica entre eles, seria indicativo de ocorrência de fatores homogenizadores da população, como autofecundação, apomixia e reprodução vegetativa (clones). Esse tipo de resultado também seria esperado na ocorrência de efeito fundador recente. Finalmente, quando ocorresse baixa similaridade genética entre os indivíduos amostrados, independentemente de sua localização geográfica, seria indicativo da ocorrência de fatores heterogenizadores, como elevada taxa de fecundação cruzada ou imigração de novos indivíduos através de animais, insetos e antropocoria (atividade humana).

Os objetivos deste trabalho foram avaliar a variabilidade genética de acessos de Bidens spp. coletados em uma propriedade, verificar a dispersão da resistência na gleba amostrada na propriedade e determinar a relação entre o coeficiente de similaridade genética e a distância geográfica entre os acessos da mesma população.

\section{MATERIAL E MÉTODOS}

\section{Coleta de sementes e material vegetal para verificação da resistência}

A coleta das sementes de Bidens spp. foi feita na propriedade denominada Fazenda Knopp, localizada no município de Almirante Tamandaré do Sul, no Planalto Gaúcho. A área amostrada correspondeu a uma gleba retangular de aproximadamente 60 ha, cultivada com soja durante cerca de 20 anos. Essa gleba foi fracionada em 100 pontos de coleta, sendo cada ponto identificado de acordo com sua posição no retângulo, conforme Figura 1. Em cada ponto foram coletadas aproximadamente 100 sementes de Bidens spp. de plantas diferentes.

As sementes de cada ponto foram semeadas em potes plásticos com volume de $200 \mathrm{~mL}$, preenchidos com substrato areia:solo (1:1) e colocados em casa de vegetação até atingirem o estádio de desenvolvimento de duas folhas. As plantas foram aspergidas com chlorimuron $200 \mathrm{~g} \mathrm{ha}^{-1}$, para confirmar sua resistência ao produto. Quando as plantas apresentavam de quatro a seis folhas, foram realizadas coletas de material vegetal. Para cada amostra, foram coletadas folhas de 20 plântulas e separadas por espécie - Bidens pilosa (BIDPI) e Bidens subalternans (BIDSU). Estas foram colocadas em envelopes de papel-alumínio e congeladas em nitrogênio líquido, até a extração do seu DNA.

\section{Extração de DNA e quantificação}

Foram realizados testes com vários protocolos de extração de DNA, devido à rápida oxidação das folhas de Bidens spp. O protocolo de extração que melhor se adaptou à extração do DNA desta espécie foi o que utilizou o detergente catiônico CTAB (Ferreira \& Grattapaglia, 1995) adaptado pelo método de Edwards et al. (1991).

A extração foi realizada em bulk's devido à baixa concentração de DNA obtido em uma folha apenas. As folhas foram maceradas na presença de nitrogênio líquido. Ao resultado da maceração foram adicionados 620 PL do tampão de extração composto de PVP 2\%, CTAB 1,1\%, TrisHCl 1M pH 8,0, EDTA 0,5M, $\mathrm{NaCl} 5 \mathrm{M}$, água "miliq" estéril, $69 \mathrm{PL}$ de SDS $20 \%$ e mais 1,6 PL de proteinase K. A emulsão

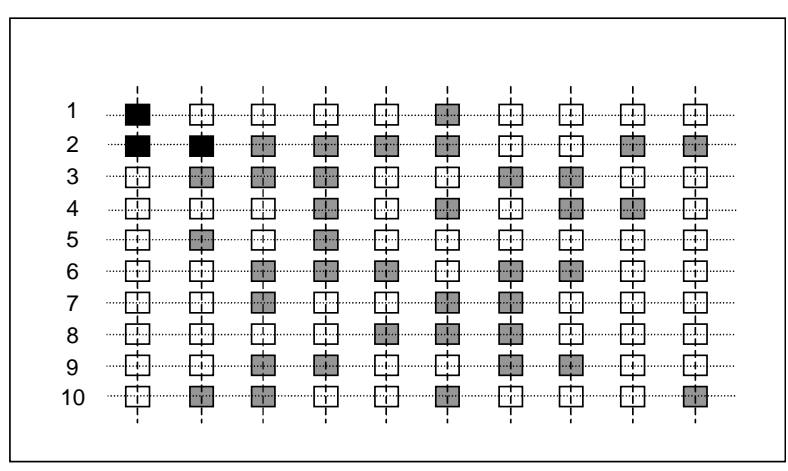

Figura 1 - Mapa da gleba onde foi realizada a coleta de sementes de Bidens spp. Pontos de coleta $(\square)$ distanciados na horizontal em 100 metros e na vertical em 50 metros. Quadrados cinza indicam locais coletados, e os pretos, provável posição do surgimento da resistência aos herbicidas inibidores de ALS na área. 
resultante dessa mistura foi colocada em banho-maria por 30 minutos a $65^{\circ} \mathrm{C}$. Após esta etapa, foram adicionados 310 PL de fenol mais 310 PL de clorofórmio:álcool isoamílico na proporção de 24:1 (v/v). Essa emulsão foi centrifugada por 10 minutos a $13.000 \mathrm{rpm}$. O sobrenadante foi separado em tubo eppendorf. Posteriormente, foi realizada a precipitação das proteínas com etanol absoluto e centrifugado. O sobrenadante contendo a fase aquosa da solução foi utilizado, e lavagens sucessivas deste com etanol $70 \%$ foram feitas. Estas lavagens devem-se à rápida oxidação do tecido vegetal durante a coleta e extração de DNA. Após cada uma das lavagens, ocorreu a centrifugação por 6 minutos a $13.000 \mathrm{rpm}$. Depois da realização das lavagens, o precipitado foi secado, sendo adicionados 50 PL de solução com TE (Tris-EDTA) 0,1X e a enzima RNAse. O precipitado foi incubado por 30 minutos a $37^{\circ} \mathrm{C}$; depois de incubado, ele foi novamente lavado com etanol 70\% e, então, centrifugado. $\mathrm{O}$ sobrenadante foi descartado e o precipitado colocado para secar. Após seco, o DNA foi ressuspenso em 100 PL de TE 0,1X. Para o controle da qualidade e estimativa da concentração do DNA, após a extração, foi realizada a quantificação com espectrofotômetro Espectronic Gênesis 2. Para a quantificação, foram diluídos 50 PL da solução de DNA extraído em 450 PL de água milliq, realizando-se medições nos comprimentos de onda de 260 e 280 nanômetros para determinação da concentração e pureza de DNA e proteína, respectivamente. A proporção dessas duas medições (OD260/OD280) indica a qualidade do DNA. Após a verificação da pureza e concentração, as amostras de DNA foram padronizadas em concentrações de $10 \mathrm{ng} \mathrm{PL}^{-1}$, que foi a concentração final da solução de trabalho.

\section{Seleção de primers e programação do termociclador}

A seleção de primers foi realizada com aqueles que produziram o maior número de amplificações de bandas no material testado (Bidens pilosa), os quais foram provenientes da Empresa Operon Technologies (Alameda, CA). Foram selecionados 26 primers, utilizados para os estudos de caracterização e avaliação da similaridade genética das populações (Tabela 1).
Tabela 1 - Identificação e seqüência dos 26 primers randômicos utilizados como marcadores RAPD

\begin{tabular}{|c|c|c|c|}
\hline Primer & Seqüência & Primer & Seqüência \\
\hline OPAD 1 & ACCGCGAAGG & OPAI 19 & AATGCGGGAG \\
\hline OPAD 4 & TCTGGTGAGG & OPAI 20 & AAAGTGCGGG \\
\hline OPAD 9 & CTCTGGAGAC & OPE 6 & AAGACCCCTC \\
\hline OPAD 10 & GGTCTACACC & OPE 9 & CTTCACCCGA \\
\hline OPAD 17 & TTTCCCACGG & OPE 10 & CACCAGGTGA \\
\hline OPAD 18 & CTGGGGACTT & OPE 11 & GAGTCTCAGG \\
\hline OPAF 18 & TTCCCGGGTT & OPE 12 & TTATCGCCCC \\
\hline OPAF 19 & CCTCTAGACC & OPE 13 & CCCGATTCGG \\
\hline OPAF 20 & GGTCTAGAGG & OPP 5 & CCCCGGTAAC \\
\hline OPAG 1 & CTACGGAGGA & OPP 6 & GTGGGCTGAC \\
\hline OPAG 19 & GTCAGGGCAA & OPP 8 & ACATCGCCCA \\
\hline OPAG 20 & TCTCCCTCAG & OPP 9 & GTGGTCCGCA \\
\hline OPAI 14 & TGACGGCGGT & OPP 10 & TCCCGCCTAC \\
\hline
\end{tabular}

As reações de PCR foram realizadas em termociclador PTC-100 (Programmable Thermal Controller MJ Research, INC) regulado para 35 ciclos; na primeira etapa, foram submetidos à temperatura de $94^{\circ} \mathrm{C}$ por três minutos, para ocorrer a desnaturação da fita de DNA - depois, um minuto a $94^{\circ} \mathrm{C}$, um minuto a $35{ }^{\circ} \mathrm{C}$ e dois minutos a $72{ }^{\circ} \mathrm{C}$. Uma incubação de 10 minutos a $72{ }^{\circ} \mathrm{C}$ foi incluída como etapa final.

\section{Análise dos dados}

Os produtos de amplificação foram analisados por eletroforese em gel de agarose 1,5\%, submetido a uma tensão elétrica de 100 Volts, em tampão TBE 1x (Tris, ácido bórico, EDTA e água), padronizando-se a migração do DNA nos géis em $10 \mathrm{~cm}$ a partir do ponto de aplicação. Os géis foram corados em brometo de etídio $\left(0,15 \mathrm{PL} \mathrm{mL}^{-1}\right)$ e visualizados em transluminador UV. Os tamanhos dos fragmentos foram determinados com a utilização do programa Kodak EDAS 290 (Eletrophoresis Documentation and Analysis System), comparando-se com o padrão de 1.000 pares de base (Gibco BRL).

Os dados coletados foram relacionados com a presença (1) ou ausência (0) de bandas. O coeficiente para o cálculo de similaridade utilizado na análise dos indivíduos foi o de Jaccard. Com os dados de similaridade foi feita a análise de agrupamento (módulo SAHN do NTSYS), utilizando o método da média das 
distâncias (UPGMA-Unweighted Pair-Group Method using and Arithmetic Average), e a construção dos dendogramas, com o auxílio do programa computacional Numerical Taxonomy and Multivariate Analysis System NTSYSpc, versão 2.1 (Rohlf, 2000).

Para realizar a regressão entre a variabilidade genética e a distância geográfica dos acessos, foi calculada a distância geográfica entre pontos de coleta das sementes e a variabilidade genética calculada através do coeficiente de Jaccard, comparando-se todas as populações entre si através do programa Statisticals Institute Analysis System (ISAS, 1999). Outra análise foi a regressão entre o coeficiente de similaridade genética e distância geográfica medida a partir dos biótipos localizados na área com suspeita de introdução da resistência e os demais acessos da gleba (Figura 1).

\section{RESULTADOS E DISCUSSÃO}

\section{Análise da similaridade genética entre acessos}

Em apenas 40 pontos de amostragem havia plantas para coleta de sementes. O teste de verificação da resistência realizado em plantas oriundas dos pontos coletados confirmou que estas são resistentes e indicou que a resistência de Bidens spp. aos herbicidas inibidores de ALS está amplamente distribuída na área amostrada.

Os vinte e seis primers utilizados no experimento produziram um total de 142 bandas, com tamanho dos fragmentos variando de 100 a 2.000 pares de base. O dendograma obtido com as duas espécies do gênero Bidens que ocorrem na área não foi suficiente para separar Bidens pilosa de Bidens subalternans (Figura 2). Esses resultados sugerem que ocorre fluxo gênico entre as espécies se estas forem geneticamente semelhantes. Segundo Ridley (2003), espécie biológica é aquela em que ocorre troca de genes (fluxo gênico) entre as populações, originando descendentes férteis.

A análise conjunta dos 40 acessos indicou similaridade média de $27 \%$ entre os acessos de cada grupo (Figura 2). O valor de similaridade entre os acessos foi baixo, o que demonstra que Bidens spp. possui elevada variabilidade genética mesmo dentro de uma mesma população.

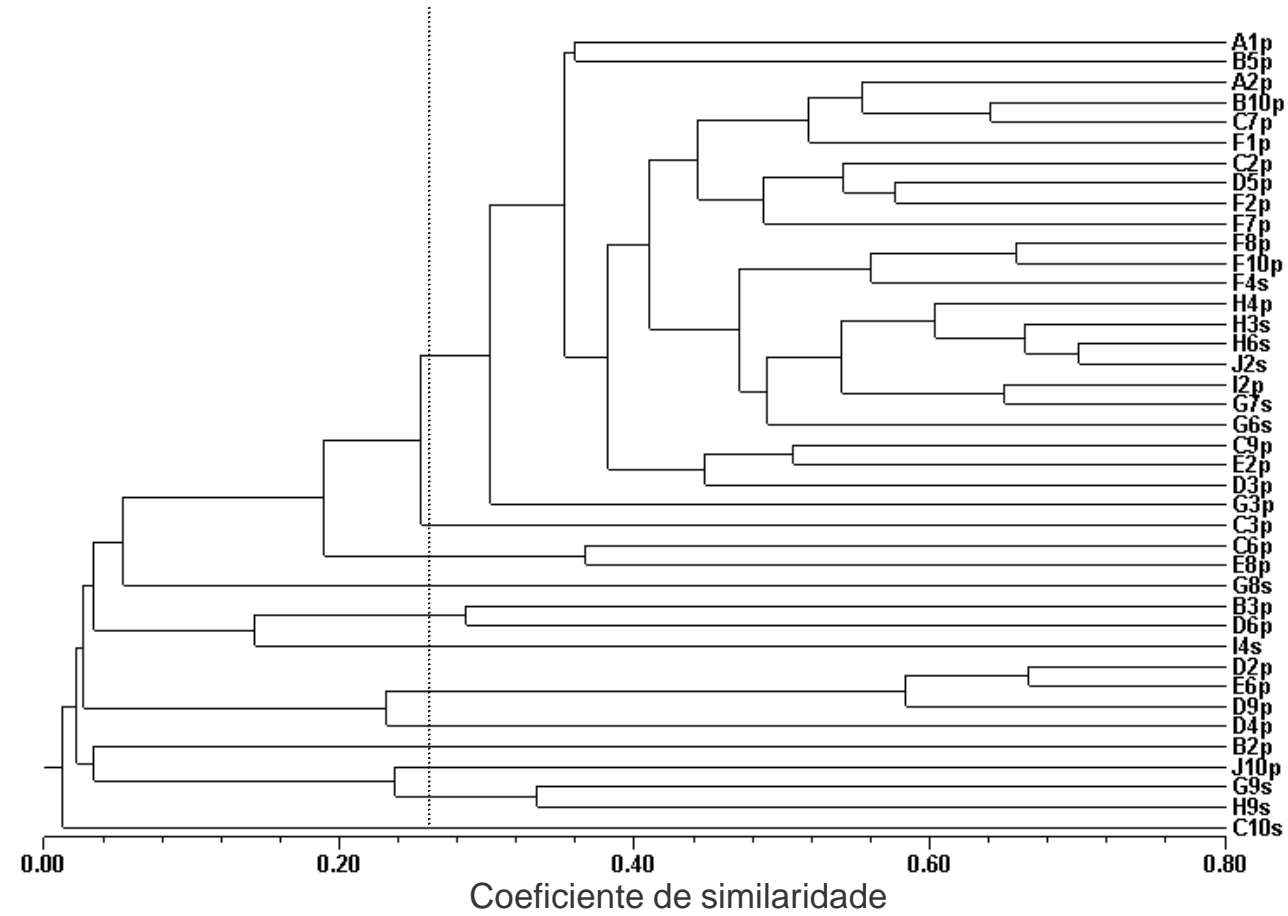

Figura 2 - Dendograma dos 40 acessos de Bidens pilosa (p) e Bidens subalternans (s), coletados em uma propriedade no Planalto Gaúcho, baseado nos dados de 142 bandas obtidas de 26 primers de RAPD, utilizando-se o método da média das distâncias UPGMA. A linha pontilhada indica a similaridade média entre os acessos, e letras com números, o local de coleta das amostras. 
Resultados semelhantes foram encontrados por Gustafson et al. (1999), que avaliaram a diversidade genética de Andropogon gerardii (planta alógama) coletada no estado de Arkansas (EUA). Esses autores concluíram que a variabilidade genética foi de 83 e 99\% entre e dentro das populações, respectivamente, o que sugeriu a ocorrência de elevado fluxo de genes entre as populações.

A variabilidade de Bidens spp. dentro de uma população é alta e ocorre fluxo gênico entre as espécies presentes na área, pois, apesar de Bidens spp. ser uma planta autógama, ela possui uma taxa de fecundação cruzada de aproximadamente 9\% (Sun \& Ganders, 1990).

\section{Relação entre a distância geográfica e a similaridade genética numa mesma população}

A elevada dispersão dos dados da Figura 3 indica que não há relação entre a distância geográfica e o coeficiente de similaridade genética. É provável que a significância do coeficiente de correlação $(\mathrm{P}<0,05)$ seja reflexo, apenas, do elevado conjunto de dados amostrados.

Os resultados não fornecem evidências suficientes para suportar as hipóteses alternativas apresentadas na introdução deste artigo . É provável que na área esteja ocorrendo simultaneamente autofecundação para homogeneizar os indivíduos, mas também forças heterogeneizadoras, fecundação cruzada, migração de sementes e recrutamento do banco de semente. Provavelmente a fecundação cruzada seja mais importante na heterogeneidade genética entre os acessos, pois contribui para a recombinação gênica.

Estimativas da correlação entre variabilidade genética e distância geográfica entre biótipos de Andropogon gerardii indicam valores de - 0,09 até - 0,16 entre essas medidas avaliadas (Gustafson et al., 1999).

Não houve regressão significativa entre o coeficiente de similaridade genética e distância geográfica medida a partir dos biótipos localizados na área com suspeita de introdução da resistência e os demais acessos da gleba (Figura 4). Os resultados dessa regressão não suportam a hipótese de dispersão da população a partir do local de introdução/surgimento relatado pelo agricultor (Figura 1). De fato, não houve significância no coeficiente de correlação $(P>0,05)$. Além disso, há grande dispersão dos pontos na Figura 4.

As implicações dos resultados obtidos para o manejo da resistência são duas: apenas a contenção do fluxo gênico, seja prevenindo o florescimento ou evitando a dispersão de sementes na área, não seria suficiente para impedir a existência de plantas resistentes; e a redução da pressão de seleção, via rotação de herbicidas de diferentes mecanismos de ação ou mistura de herbicidas diferentes, é prioritária para evitar novos focos de plantas resistentes na área.

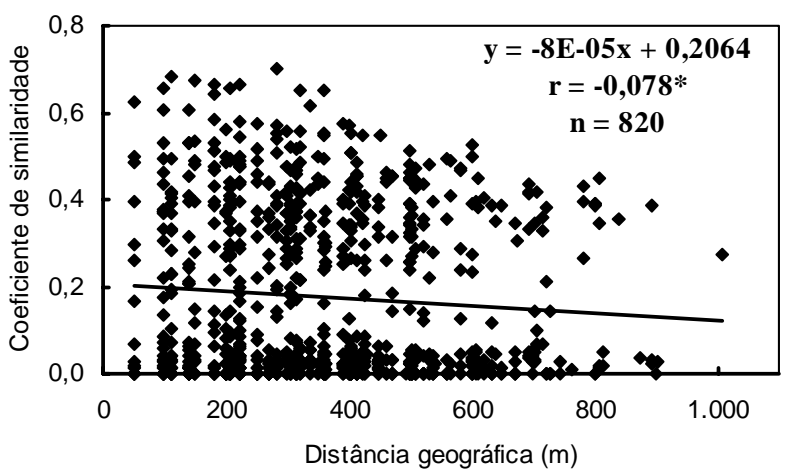

Figura 3 - Regressão entre distância geográfica e distância genética avaliada dentro da população de plantas de Bidens spp. * indica significância estatística $(\mathrm{P}<0,05) ; \mathrm{n}$ indica o número de pares de dados testados.

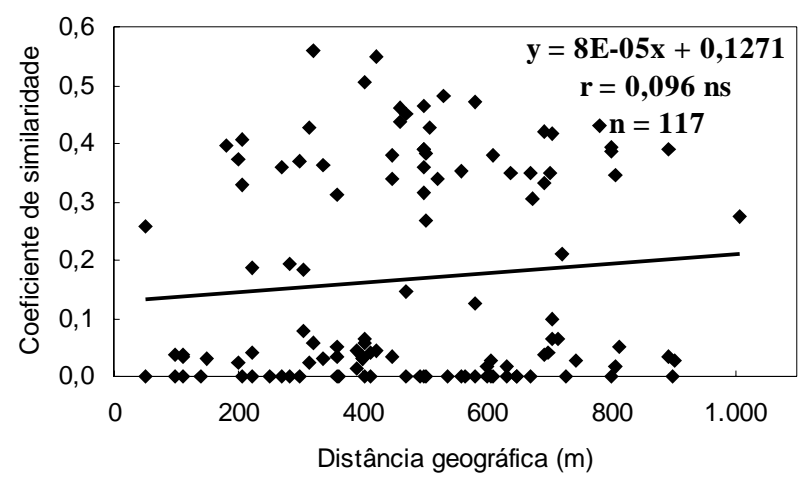

Figura 4 - Regressão entre distância geográfica e distância genética avaliada dentro da população de plantas de Bidens spp. ns indica não-significância em nível de probabilidade $(\mathrm{P}>0,05)$. 
Os resultados permitem fazer três especulações. Primeiramente, pode ter ocorrido mais de um evento de seleção de Bidens spp. resistente ao herbicida chlorimuron na área. Em segundo lugar, pode ter ocorrido a introdução da resistência aos inibidores de ALS na área em local diferente do indicado pelo agricultor. Finalmente, pode ter ocorrido fluxo gênico entre os biótipos na área através de máquinas, dispersão de pólen e fluxo migratório de sementes.

Os fatores que independentemente favorecem a seleção de populações de plantas daninhas resistentes são variados, destacandose a freqüência inicial do alelo de resistência e o fluxo gênico de uma planta resistente para outra não-resistente. Além disso, o uso intensivo de herbicidas pertencentes a um único mecanismo de ação e a monocultura proporcionam elevada pressão de seleção e alteram a população de plantas daninhas em uma área, favorecendo a seleção das resistentes (Gealy et al., 2003).

O efeito fundador provavelmente não ocorreu na área em razão de dois fatores: a grande variabilidade existente entre as plantas devido ao fluxo gênico entre as plantas da área; e a dispersão de sementes entre áreas da propriedade e a gleba amostrada, por meio da elevada atividade agrícola desenvolvida e através de pássaros e outros animais.

Este trabalho demonstrou que: os acessos de Bidens spp. apresentam grande variabilidade genética dentro da população; as espécies Bidens pilosa e Bidens subalternans não puderam ser separadas pela análise molecular com RAPD; plantas com resistência aos herbicidas inibidores de ALS estão disseminadas em toda a área amostrada dentro da propriedade; e não existe relação entre distância geográfica e similaridade genética entre os acessos da população.

\section{LITERATURA CITADA}

BOURGEOIS, L.; MORRISON, I. N. A survey of ACCase inhibitor resistant wild oat in high risk township in Manitoba. Can. J. Plant Sci., v. 77, n. 4, p. 703-708, 1997.

DARMENCY, H.; GASQUEZ, J. Inheritance f triazine resistance in Poa annua: consequences for population dynamics. New Phytol., v. 89, p. 487-493, 1981.
EDWARDS, K.; JOHNSTONE, C.; THOMPSON, C. A simple and rapid method for the preparation of plant genomic DNA for PCR analysis. Nucleic Acids Res., v. 19, n. 6, p. 1349-1350, 1991.

FERREIRA, M. E.; GRATTAPAGLIA, D. Introdução ao uso de marcadores RAPD e RFLP em análise genética. Brasília: Embrapa: Cenargen, 1995. 221 p.

GEALY, D. R.; MITTEN, D. H.; RUTGER, N. Gene flow between red rice (Oryza sativa) and herbicide-resistant rice (O. sativa). Implications for weed management. Weed Technol., v. 17, n. 3, p. 627-645, 2003.

GUSTAFSON, D. J.; GIBSON, D. J.; NICKRENT, D. L. Randon amplified polymorphic DNA variation among remnant big bluestem (Andropogon gerardii Vitman) populations from Arkansas' Grand Prairie. Molec. Ecol., v. 8, n. 10, p. 1693-1701, 1999.

GUTTIERI, M. J.; EBERLEIN, C. V.; SMITH, M. C. A. DNA sequence variation in domain A on acetolactate synthase genes of herbicide-resistant and susceptible weed biotypes. Weed Sci., v. 40, n. 1, p. 157, 1992.

HOLT, R. D.; HOCHBERG, M. E. When is biological control evolutionary stable (or is it?). Ecology, v. 78, n. 14, p. 1673-1683, 1997.

STATISTICAL INSTITUTE ANALYSIS SYSTEM - SAS. User's guide. 8.ed. Cary: 1999. 846 p.

MAXWELL, B. D.; MORTIMER, A. M. Selection for herbicide resistance. In: POWLES, S.; HOLTUM, J. (Eds.). Herbicide resistance in plants: biology and biochemistry. Boca Raton: CRC, 1994. p. 1-20.

RIDLEY, M. Evolution. Oxford: Blackwell, 2003. 768 p.

ROHLF, F. J. Numerical taxonomy and multivariate analysis system. Port Jefferson: Applied Biostatistics, 2000. $38 \mathrm{p}$.

SILVERSTOWN, J. W.; LOVETT DOUST, J. Introduction to plant population ecology. Oxford: Blackwell Scientific, 1993. $102 \mathrm{p}$.

STANKIEWICZ, M.; GADAMSKI, G.; GAWRONSKI. Genetic variation and phylogenetic relationships of triazineresistant and triazine-susceptible biotypes of Solanum nigrum - analysis using RAPD markers. Weed Res., v. 41, n. 2, p. 287-293, 2001.

SUN, M.; GANDERS, F. R. Outcrossing rates and allozyme variation in rayed and rayless morphs of Bidens pilosa. Heredity, v. 64, n. 1, p. 139-143, 1990.

WINKLER, L. M.; VIDAL, R. A.; BARBOSA NETO, J. F. Aspectos genéticos envolvidos na resistência de plantas daninhas aos herbicidas. R. Plantio Direto, v. 70, n. 4, p. 21-24, 2002.

Planta Daninha, Viçosa-MG, v. 24, n. 1, p. 149-155, 2006 